Beata Iwona KURYŁOWICZ

\title{
NIEZŁOŻONA ODMIANA PRZYMIOTNIKÓW I IMIESŁOWÓW PRZYMIOTNIKOWYCH W PODLASKICH AKTACH URZĘDOWYCH Z DRUGIEJ POŁOWY XVI W.
}

Celem niniejszego artykułu jest przedstawienie i scharakteryzowanie form prostych przymiotników i imiesłowów przymiotnikowych występujących w „Aktach albo sprawach sądów miasta knyszyńskiego 1553-1580" ${ }^{1}$ na tle ogólnopolskiej normy językowej.

Wiek XVI to czas normalizacji deklinacji przymiotników. Następne stulecia odziedziczyły po nim stan bardzo zbliżony do obecnego. Między innymi wtedy to doszło do redukcji „deklinacji rzeczownikowej do pozycji reliktu w nom. m. i f. (funkcja orzecznikowa)" ${ }^{2}$. Dlatego interesujące wydaje się sprawdzenie, jak na tym ogólnym tle rysuje się problem przymiotników prostych obecnych $\mathrm{w}$ podlaskich dokumentach. Czy rzeczywiście występują one szczątkowo i tylko w funkcji orzecznika?

Badane teksty stanowią zbiór dokumentów związanych z kupnem i sprzedażą nieruchomości, długami, kradzieżami, pobiciem, oszczerstwami szkodzącymi dobrej sławie obywateli oraz różnego rodzaju umowami zawieranymi przez mieszkańców miasta.

$\mathrm{Z}$ konfrontacji wydania drukowanego $\mathrm{z}$ rękopisami ksiąg miejskich Knyszyna wynika, że w niektórych miejscach są one różne. Dlatego przy formach, które w druku mają inną końcówkę niż w rękopisach, podaję ich pierwotną postać $\mathrm{z}$ numerem karty rękopisu.

\footnotetext{
1 Akta albo sprawy sqdów miasta knyszyńskiego. 1553-1580, t. I, Białystok 1999. Dokumenty wydał i opatrzył obszernym wstępem Józef Maroszek.

2 S. Rospond, Język i artyzm językowy Jana Kochanowskiego, Wrocław 1961, s. 103.
} 


\section{Rodzaj męski}

W badanym materiale proste formy przymiotników i imiesłowów występują najliczniej w mianowniku l. poj. Obok form dziś już nie używanych, spotykamy tu również takie, które w skostniałej postaci występują we współczesnej polszczyźnie: winien 39 oraz z negacją nie winien (w sumie ponad 100 przykładów), powinien 118 (oraz 5 innych przykładów), gotów 139 (oraz 11 innych użyć), wesół 185, wart 181, 183. Ostatni przykład zwraca szczególną uwagę, ponieważ, jak podaje Petr, przymiotnik wart $\mathrm{w}$ postaci niezłożonej przedostał się $\mathrm{z}$ języka niemieckiego do polszczyzny w 2 poł. XVII wieku ${ }^{3}$. Tymczasem wart w podlaskich dokumentach odnotowany został już w 1557 r. Wobec tego należy przesunąć czas owego zapożyczenia $z$ wieku XVII na XVI.

Dużo większe zróżnicowanie leksykalne obserwujemy wśród przymiotników i imiesłowów prostych, które po XVI wieku wyszły z użycia: $\dot{z} y w 148,342$, praw 47, 229, 237, niebezpieczen 362 , pilien 246,228 , chrom 366 , płacen 259, 260, 267 (płaczem 245 - nie chce mi płaczem byc), dłużen 201 (oraz 17 innych poświadczeń), wolen 33 (oraz 48 innych przykładów), postuszen 151, winowat 37 , świadom 258 , nie przypędzon, ani przymuszon 89 , przymuszon 118, pytan 69 , upomienion 379 , oskarżon 375 , ukazan 125 , ostawion 200, uchwycon 124, osadzon k. 77 (sqdzony s. 125), Pisan 298, przywrócon 257, nakazan 357, odłożon 355, obwinion 344, sqdzon 156, skaran 325, karan 344, zdan 379, pozwan 226, dan 344, 252, podan 311, 384, założon 317, złożon 360, 372, skazan 69, 311, przydan 311 (oraz 14 innych form).

Wśród form prostych wyodrębnia się znaczeniowo grupa przymiotników dzierżawczych pochodnych od imion własnych: Lewkow 102, Serafinow 109, Mikołajow Szarszaninow 135, Jurkow 50, Czuczerejow 249, Postrzygaczow 301, Dmosikow 338.

W mianowniku l. mn. poświadczona została końcówka -y: mianowat na Tarussę i na Slawskie $i$ Niewiarowskiego, które sq wyżej opisany 69, pomieniony sq (rajcy) 224, 225, 227, 230, 236, 238, 242, nieprzymuszony zeznali 81 , wyżej mieniony porucznicy k. 71v, przerzeczony światkowie k. 88,

3 J. Petr, Niezłożone formy przymiotników w historii i dialektach języka polskiego, Wrocław - Warszawa - Kraków 1969, s. 28, 108. 
przerzeczony miesczanie k. 89 (przerzeczoni s. 113, 138, 139), nie będq̨c przymuszeni, ani przypędzony k. 69v (przypędzeni s. 111), nie przymuszony, ani zwiedzeni 172.

$\mathrm{W}$ innych przypadkach przymiotniki i imiesłowy proste występują zdecydowanie rzadziej: w dop. 1. poj. - z sziera (tzn. z surowego) korzenia 56, w cel. l. poj. - po pianu k. 233 (w wydaniu po pijanemu s. 370), w bier. l. mn. - przydał urzqd...ławniki przysiężny k. 223v (w wydaniu ławniki przysiqżne s. 338). W ostatnim przykładzie nie dziwi stary biernik przy rzeczowniku męskoosobowym zamiast występującej $w$ tej funkcji formy dopełniacza. Z badań Wojciecha Ryszarda Rzepki wynika, że lata 1574-1590 są dopiero wstępną fazą kształtowania się męskoosobowego gen.-acc. pl. przymiotników i liczebników porządkowych użytych rzeczownikowo jako dopełnienia ${ }^{4}$. Już wcześniej Marian Kucała stwierdził, że to zaimki i przymiotniki (od nich rozpoczął się proces rozwoju form acc. = gen. pl.) narzucają swoją formę rzeczownikom, wtedy gdy przydawka znajduje się przed określonym rzeczownikiem. Jednakże w tekstach z początku XVII w. odnalazł on wiele form starego biernika zaimków i przymiotników występujących po rzeczowniku ${ }^{5}$.

\section{Rodzaj żeński}

W badanym materiale trudno wskazać niewątpliwe przymiotniki proste w mianowniku l. poj., ponieważ w podlaskich dokumentach rękopiśmiennych, w zależności od ręki pisarskiej, albo wcale nie są oznaczane samogłoski pochylone, albo czynione jest to w sposób niekonsekwentny. Można jednak przypuszczać, na podstawie tak licznie poświadczonych męskich form przymiotników prostych w mianowniku l. poj., że również wśród żeńskich w mianowniku l. poj. pewna grupa przykładów (szczególnie w funkcji orzecznika) to formy niezłożone. Dodać należy, że najwięcej przykładów przymiotników prostych ro-

\footnotetext{
4 W. R. Rzepka, Dopetniacz $w$ funkcji biernika męskich form osobowych $w$ liczbie mnogiej $w$ polszczyźnie XVII w., Wrocław - Warszawa - Kraków - Gdańsk 1975, s. 29.

5 M. Kucała, Rola zaimków i przymitnikớw $w$ powstaniu męskoosobowego acc.-gen. plur., w: Symbolae polonicae in honorem Stanislai Jodlowski, Wrocław - Kraków - Warszawa - Gdańsk 1972, s. 87-92.
} 
dzaju żeńskiego przypada właśnie na mianownik l. poj. Jerzy Petr zaobserwował, że w XVI w. istnieje wyraźna morfologiczna zależność między przymiotnikami prostymi w mianowniku l. poj. r. żeńskiego a przymiotnikami prostymi w mianowniku l. poj. r. męskiego. Polega ona na tym, że nie występuje taki przymiotnik prosty $\mathrm{w}$ mianowniku 1. poj. r. żeńskiego, którego nie byłoby w mianowniku l. poj. r. męskiego ${ }^{6}$. Można zatem przypuszczać, że formy typu: była...winna 313, nie chce mi płatna być 267, ostała dłużna 242, gotowa była 55, żona Matisowa 52 , była wolna 79 są przymiotnikami prostymi.

W przypadkach zależnych przykłady przymiotników prostych są pewniejsze, ale ich występowanie szczątkowe. W dop. l. poj. - pilnowat przysięgi na rok złożony 59, w mian. 1 . mn. - İं mi ostały dłużny 224, Iż $m u$ winny 224, dzieweczki nie przypędzony ani przymuszony 106, wolny ty obie strony 70 .

\section{Rodzaj nijaki}

Formy proste imiesłowów w rodzaju nijakim występują częściej niż przymiotników. Podobnie jak w wypadku r. męskiego i żeńskiego najwięcej przykładów przypada na mianownik 1. poj.: aby to lice okazano beło k. 77 (okazane beło 125), było jemu położono 133, którq wyżej pomieniono jest 213, było...winno (dziecko) 113, było jemu opisano 238, to mięso było precz zarzucono 258, co wyżej pomieniono jest 208, aby to jawno...byto 138, jest...zapisano 302, 304, Co jest do ksiag zapisano 355, 368, 376, k. 221 (zapisane s. 332), jest szerzej opisano 113, wyżej opisano jest 240, 251, jest opisano 262, 263. W mianowniku l. mn. występują takie przykłady, jak: aby beła podana (dobra) k. 223v (podane s. 337); w narzędniku l. mn. - targnąt się rękąm albo nieuczciwy słowy 87.

Zenon Klemensiewicz poświadcza obecność imiesłowów prostych w mianowniku r. nijakiego, gdy w funkcji podmiotu występują zaimki to, co, ono, jeszcze w XVII wieku? ${ }^{7}$.

6 J. Petr, Niezłożone formy..., s. 52.

7 Z. Klemensiewicz, Szczątki niezłożonej odmiany przymiotników w staropolszczyźnie, „Prace Filologiczne" t. XII, 1927, s. 124 . 
Wiele podobnych form wynotowała Zofia Kurzowa z AWK. Z jej badań wynika, że w polszczyźnie północnokresowej występowały one jeszcze w XVIII w. i stanowiły "na tle języka ogólnego rys archaiczny” 8 .

Niezłożone formy przymiotników i imiesłowów przymiotnikowych występują w Aktach... najczęściej w funkcji orzecznika ${ }^{9}$, np.: ostał jemu winien 163, ostał praw 47, jest wolen 89, był wiart 181, byt wesót 185, jest...ostawion 200, bet ukazan 125, byt pozwan 226, byt...złożon 372 itp.

Zdaniem Klemensiewicza, przymiotniki proste od XVI w. rzadko występuja $w$ tej funkcji, natomiast wśród imiesłowów formy proste przeważają w pierwszej połowie tego stulecia „później mnożą się złożone" ${ }^{10}$. Badany materiał może zatem wydawać się bardzo archaiczny. Jednakże najliczniej poświadczone są takie przymiotniki proste, które w skostniałej postaci używane są również dzisiaj, a jednocześnie "wykazują indywidualną skłonność do formy niezłożonej, przynajmniej w orzeczniku" ${ }^{11}$, czyli takie jak: winien ${ }^{12}$, powinien, wesót, gotów, wart, $\dot{z} y w$.

W zakresie imiesłowów $\mathrm{w}$ badanym materiale zdecydowaną większość stanowią formy złożone. Na około 240 przykładów tylko 60 ma formę niezłożoną. Materiał ksiąg miejskich Knyszyna potwierdza zatem opinię Klemensiewicza, że w drugiej połowie XVI w. nastąpił przyrost imiesłowowych form złożonych.

Przymiotniki proste $w$ funkcji przydawki występują $w$ analizowanych dokumentach raczej rzadko. Najliczniej reprezentowaną grupa

8 Z. Kurzowa, Język polski Wileńszczyzny i kresów pótnocno-wschodnich XVI-XX w., Warszawa Kraków 1993, s. 181.

9 Pod uwagę biorę orzecznik wyrażony tylko przez przymiotnik i imiesłów przymiotnikowy $\mathrm{w}$ mianowniku r. męskiego i nijakiego, ponieważ trudno jest $\mathrm{w}$ badanych dokumentach odróżnić formy proste od złożonych $\mathrm{w}$ mianowniku r. żeńskiego.

10 Z. Klemensiewicz, Szczq̨tki nieztożonej..., s. 124, 129.

11 Tamże, s. 128.

12 W Aktach... przymiotnik złożony winny poświadczony jest zaledwie kilka razy: s. 160, 181. Prawdopodobnie również przymiotnik wolen w znaczeniu "wolno mu coś zrobić" wykazywał indywidualną skłonnosć do formy prostej. Wolny poświadczony jest zaledwie kilka razy na str. 87, 90, 128. 
wśród nich są przymiotniki dzierżawcze z przyrostkiem -ow ${ }^{13}$, np. Jurkow syn 50. Ponadto $w$ tej funkcji zdarzają się także przymiotniki o innej budowie słowotwórczej, ale w przypadkach zależnych, np.: z sziera (tzn. z surowego) korzenia 56, w bier. 1. mn. - przydał urząd...ławniki przysiężny k. 223v (w wydaniu ławniki przysiażne s. 338), w narz. 1. mn. - targnąt się rękąm albo nieuczciwy słowy 87.

Skoro od w. XVI nie spotyka się przymiotników prostych w przydawce, z wyjątkiem przymiotników dzierżawczych z przyrostkiem -ow, -in pochodnych od imion własnych lub pospolitych ${ }^{14}$, można stwierdzić, że badany materiał pod tym względem reprezentuje stan zgodny z ogólnopolską normą językową.

W Aktach... przymiotniki proste występują także w funkcji przydawki orzekającej ${ }^{15}$, np.: pan Jakub Czech jedzie wesót 185, pilność uczynit praw 237, iż praw stawił 229, nie stanał praw Grzegorz 237. Petr wyjaśnia, że $w$ tej funkcji niezłożone formy przymiotników najczęściej używane były w XV w., a od wieku XVI ich liczba kurczy się coraz bardziej ${ }^{16}$.

$\mathrm{W}$ badanych dokumentach przymiotniki proste pełnią także funkcję modalną ${ }^{17}$. W tej roli notujemy trzy formy: powinien, winien i gotów. Dwie pierwsze wyrażają modus konieczności, np.: będzie powinien czynsz na każdy rok płacić 152, a ja będę powinien od niego zapłacić 215, tedy będzie powinien zapłacić 216, będę powinien dopuścić 261, winien będzie Jan dosyć czynić 338, winien być na wselkich miescach i też dać się winienem 231, winien oddać 230, będzie winien zapłacić 219, nie winien dać tej liphy 154; ostatnia wyraża tylko prostą dyspozycję do realizacji dictum ${ }^{18}$, np.: Iżem ja gotów

13 Szlifersztejnowa uważa, że przymiotniki dzierżawcze pełnią funkcję orzeczników, ponieważ „Przymiotnik dzierżawczy nie wymienia tu bowiem jednej z podstawowych cech podmiotu, bez której rzecz nazwana przez podmiot po prostu nie istnieje, ale orzeka cos o podmiocie, jest wyrazem postawy sądzącej wobec niego, uwydatniając cechę przypadkowo różniącą dany przedmiot od innych przedmiotów tejże klasy, nie mającą żadnego wpływu na ogólne wyobrażenie nazwanej rzeczy". Ponadto twierdzi ona, że niemal wszystkie przytoczone przez nią formy niezłożone przymiotników dzierżawczych użyte zostały $w$ funkcji przydawki orzeczeniowej, co umożliwiło występowanie w średniowieczu w "dosć pokaźnej liczbie przypadków”. S. Szlifersztejnowa, Przymiotniki dzierżawcze $w$ języku polskim, Wrocław 1960, s. 34-35, 89.

14 Z. Klemensiewicz, Szczątki niezłożonej..., s. 129.

15 Por. J. Petr, Niezłożone formy..., s. 67-72.

16 Tamże, s. 70-71.

17 Tamże, s. 78-85.

18 Termin przejęty od J. Petra, op. cit., s. 84 . 
na ranach swoich podeprzeć cielesna przysięgq 139, Gotów się tego wsitkiego sprawić 230, gotów ja prawem instygować 251, bet gotów dosyć uczynić 346, jestem gotów $i$ teraz położyć 369, beł gotów przysiqc 372, był gotów przysięgi stuchać 375.

Przytoczony materiał wskazuje, że pod względem użycia prostych form przymiotników i imiesłowów przymiotnikowych podlaskie dokumenty cechuje konserwatyzm językowy. W księgach miejskich Knyszyna przymiotniki i imiesłowy proste nadal występują dość licznie, w funkcji nie tylko orzecznika, ale również przydawki, przydawki orzekającej oraz w funkcji modalnej; natomiast ich różnorodność świadczy o tym, że w drugiej połowie XVI wieku na Podlasiu są one kategorią ciągle żywą. 